\title{
1. Introduction: innovation in tourism industries
}

\author{
Gry Agnete Alsos, Dorthe Eide and \\ Einar Lier Madsen
}

\section{INTRODUCTION}

Tourism is one of the fastest-growing industries globally. Over the past two decades, the average growth rate of the tourism sectors in OECD countries has exceeded GDP growth, and many non-OECD countries have experienced even higher growth in their tourism sectors (OECD, 2010). Tourism plays an important role in economic development by sustaining employment and bringing in foreign currency. Growth is driven not only by increasing wealth and economic development but also by the tourism industry's ability to offer new products and experiences. Tourism firms operate in a competitive market that is characterized by high turbulence and rapid changes. To compete effectively, tourism firms must be highly innovative either in cutting costs or in offering new, high-quality products that meet customer demand. No country or region can rest on its natural endowment or cultural heritage. Strategies to support innovation are needed to remain competitive in the global tourism market (OECD, 2010).

The tourism sector is presently undergoing extensive change because of a transition to more experience-based products (Sundbo et al., 2007) and because of strong market growth (Lordkipanidze et al., 2005). This transformation places even stronger demands on tourism firms to innovate. Product life spans are becoming shorter, requiring firms to introduce new and better products more frequently. The capacity for firms to change, develop new products and adapt to market changes is therefore crucial to firm and industry performance.

Research-based knowledge on innovation in tourism firms remains scarce. Mainstream innovation research very seldom includes tourism, and tourism research has only examined innovation within firms to a small extent. The dominating theories on innovation primarily relate to the production of goods and technology and, to a lesser extent, to service innovation (Gallouj \& Djellal, 2010). Research with regard to innovation in service sectors has increased, and more recently scholars 
have examined innovation in experience industries, resulting in a debate concerning the applicability of mainstream innovation theory to innovation in the service and experience sectors. Whereas some authors favor an assimilation strategy that transfers theories, models and measurements from mainstream innovation research and adapt them to a new sector context, other scholars favor a divergent strategy that develops new, context-sensitive theories and measures. This book aligns with a third group of authors (Hjalager, 2002; Hipp \& Grupp, 2005; Miles, 2005; Vence \& Trigo, 2009; Gallouj \& Savona, 2010; Sundbo et al., 2010) by adopting a mixed approach. Using this approach, theories, models and measures are adapted from the mainstream innovation literature. The mainstream concepts are then supplemented, challenged and further developed through studies from the tourism industries, taking into account that this context offers specific characteristics regarding innovation. These characteristics include the overlap created between products and processes since services and experiences involve and depend on some degree of customer co-creation. Hence, parts of the production process take place during consumption. Further, tourism products are often packages built from a set of services and products from various suppliers. These characteristics are not only important to understand innovation within tourism but also to potentially inform and stretch the boundaries of mainstream innovation research.

This handbook incorporates current research on innovation in tourism industries and examines relevant issues through four main themes. The first theme focuses on the way in which innovation in tourism is defined and measured and discusses the various forms of innovation in the tourism sector. The second theme relates to the various sources of innovation in the sector and examines how innovation occurs. The third theme addresses innovation processes at the firm level, whereas the fourth theme discusses innovation processes at the tourism destination level. Contributions are drawn from international research settings and offer an interdisciplinary approach to the subject. The handbook will challenge current debates and enrich existing literature. We hope that the handbook will appeal to academics within tourism, innovation and small business studies and to policymakers and others interested in supporting tourism industry innovation.

This introductory chapter establishes the premise of the book by introducing the core issues related to innovation in tourism and by presenting the contributions from each of the four themes. We also present findings from the research presented in the book and discuss these findings in relation to the experience turn in tourism research and the implications for studying tourism innovation. 


\section{INNOVATION IN TOURISM}

Like other service sectors, the tourism industry is often viewed as less innovative than more manufacturing-oriented and technology-oriented industries. Within the service and tourism innovation literature, a debate exists regarding the possible incompatibility between product and service innovation (Krizaj et al., 2012) and the particulars of tourism innovation (Jacob et al., 2003; Walder et al., 2006; Hall \& Williams, 2008). The primary issues relate to the characteristics, measurement specifics and different descriptive models of innovation in the service industry and tourism. Camisón and Monfort-Mir (2012), for example, outline the limitations of a too strict Schumpeterian approach to tourism innovation. These researchers indicate that innovation at the individual firm level might not be appropriately evaluated using indicators intended for measuring innovation at national or regional levels. Furthermore, it has been questioned whether standard measurement tools for general innovative activities capture the wide variety of the characteristics of all services included in multidisciplinary tourism (Tribe, 1997; Liburd, 2012). Camisón and Monfort-Mir (2012) offer a set of proposals in the context of a scoreboard to provide a comprehensive view of a tourism firm's technological and organizational innovations and its innovative capabilities. The proposals combine Schumpeterian theory and a dynamic capabilitiesbased approach, also making cross-national comparisons feasible.

Despite measurement and comparison problems, tourism businesses historically provide outstanding examples of significant innovation. Hjalager (2010), for example, suggests that 'tourism has been a phenomenon characterized by immense innovativeness' (p.1), citing a range of examples of distinctive individuals and enterprises that diverged from conventional thinking. The examples include creating travel or other experiences for a completely new segment of customers (Thomas Cook), offering movie and media-synergized theme parks (Disney Corporation) appealing not only to local audiences but also to global interests (Weth, 2007), and the development of new organization of food provision (McDonald's) to such an extent that the concepts served as inspiration for the entire catering sector and beyond (Ritzer, 2008). Another example of innovation is Ryanair, which offers extremely low fares using remote airports, providing airplane travel to new customers (Furseth \& Cuthbertson, Chapter 9 this volume). Hence, there is no doubt that tourism firms can be innovative.

However, defining innovation in this industry has not been clear cut. Although no specific definition of innovation in tourism has been agreed upon, there appears to be an acceptance, at least in empirical studies, that innovation is understood to be everything that can be characterized as new 
(Johannessen et al., 2001), i.e., differs from business as usual or previous practice (Hjalager, 2010). For example, Kanter (cited in Hall \& Williams, 2008, p. 5) defines innovation as the following:

Innovation refers to the process of bringing any new, problem-solving idea into use. Ideas for reorganizing, cutting cost, putting new budgetary systems, improving communication or assembling products in teams are also innovations. Innovation is the generation, acceptance and implementation of new ideas, processes, products or services. Acceptance and implementation is central to this definition; it involves the capacity to change and adapt.

Furthermore, according to Hjalager (2010, p.2), ‘. . a significant extent of innovation studies in tourism still rely on explorative and qualitative cases where the phenomenon is investigated and explained from a number of angles and where rigid definitions are less prevalent'. The lack of specific definitions of innovation in tourism has been indicated as a challenge for the comparisons of quantifiable levels of innovation between industries and/or between tourism industries in different countries (Hall, 2009). However, as seen in this volume and among an increasing number of researchers, many studies take Schumpeter's (1934) innovation theory as a point of departure (Hall, 2009; Weiermair, 2006; Hjalager, 1997; Fagerberg, 2005; Drejer, 2004; OECD and Statistical Office of European Communities, 2005). Schumpeter noted that the creation of new knowledge or the new combination of existing knowledge is transformed into innovations in an enterprise. Schumpeter's view of innovation was broad and not limited to technological innovation; however, he focused on more radical and market transforming innovations that contribute to creative destruction rather than on incremental, new-to-the-firm innovations.

Following Schumpeter's analysis the following five types of innovation can be distinguished, all of which can also be found in tourism industries: (1) the creation of new products or services (product and service innovation), (2) new production processes (process innovation), (3) new markets (market innovation), (4) new suppliers (input innovation), and (5) changed organization or management systems (organizational innovation). Product, process, organizational/managerial and market innovations constitute the main body of innovation categories (Weiermair, 2006). There are also examples of attempts in the literature to consider the particularities of innovation in tourism by adding other innovation categories such as distribution innovations and institutional innovations (a new, embracing collaborative/organizational structure, e.g., networks and alliances, or a legal framework that efficiently redirects or enhances the business in certain fields of tourism) (Hjalager, 2010) and reverse community innovations and spin-offs into the educational system in innovation 
systems (Hjalager et al., 2008). Innovation in this perspective is nurtured and stimulated when firms interact and cooperate with external actors.

When understood based on Schumpeter's innovation theory, innovation has been viewed as an outcome, the innovative performance itself. Conversely, from a resource-based view innovation is viewed as a capability that is a source of innovative performance (Camisón \& Monfort-Mir, 2012). In tourism innovation research, the preference toward the study of innovation process outcomes from a Schumpeterian point of view has been focused more intensively on empirical research applied to tourism enterprises (Camisón \& Monfort-Mir, 2012; Novelli et al., 2006). Some studies have explored the influence of market and enterprise characteristics on incremental and radical innovations (Gallouj \& Sundbo, 1998; Hjalager, 2002; Martínez-Ros \& Orfila-Sintes, 2009; Volo, 2004) and on the decision to innovate in products or processes (López-Fernández et al., 2009; Orfila-Sintes et al., 2005). Other studies have analyzed certain technological innovations, particularly those related to the diffusion of information technologies in tourism industries (Camisón, 2000; Jolly \& Dimanche, 2009; Law \& Jogaratnam, 2005).

This handbook examines innovation in tourism from a broad perspective. The book discusses the perspectives, categorizations and measurement of tourism innovation and examines the various sources of innovation within the tourism sector. Further, the handbook presents studies concerning innovation processes within tourism firms and at the destination level. Each of these themes will be briefly presented in the next sections.

\section{INNOVATION IN TOURISM: ISSUES AND PERSPECTIVES}

Innovation research has examined innovation processes within firms; innovation in the systems of several firms, institutions and governmental bodies; the way in which innovation varies over time and space; and the outcomes of innovation (Fagerberg, 2005). As previously mentioned, mainstream innovation literature has defined innovation as the new combinations of production factors such as the production of new goods, the introduction of new processes, the opening of new markets, the access to new sources of raw materials and intermediates, and the reorganization of an industry (Schumpeter, 1934). This definition can be traced to the influential Oslo Manual on innovation research (OECD and the Statistical Office of European Communities, 2005) that is widely used, for example, in the Community Innovation Survey (CIS). 
However, the perspective reflected in these prevailing definitions, theories and measurements of innovation is primarily based upon studies within manufacturing and may not be equally relevant for service and experience producing industries (Gallouj \& Djellal, 2010). Despite a growing body of literature on innovation in services, knowledge remains scarce and fragmented compared with knowledge related to innovation in manufacturing sectors. The literature on innovation in tourism industries, in which not only services but also experiences provide distinct features regarding the innovation process, is even scarcer (Hjalager, 2010). The first section of this book addresses the concept of innovation in relation to tourism. The focus, however, is not on comparing innovation in tourism industries to innovation in other sectors. Instead, this section explores the various characteristics of innovation in tourism and discusses how innovation can be understood and measured in this context.

The Oslo Manual differentiates between project innovation and process innovation, the two types of innovation most typically studied (Fagerberg, 2005), and later between market innovation and organizational innovation. Although these demarcations have proven to be useful in innovation studies related to manufacturing industries, this differentiation is not as straightforward when considering service innovation or experience innovation. As Rønningen and Lien (Chapter 2) indicate, it can be difficult to distinguish between the product and the production process in regard to services because services usually are produced when they are consumed. Consequently, it is also difficult to make a clear distinction between product and process innovation. Rønningen and Lien further note that distinguishing between different types of innovation may be even more difficult in tourism industries because tourism products are often packages built from a set of services delivered from several firms. Hence, a package may be new to the market and innovative by definition even though the sub-services delivered by each firm may not be new. Further, it is not clear whether a package innovation is a new product, a new process, or a new organizational structure such as a new collaboration. In their study, Rønningen and Lien find that if a tourism firm has provided one type of innovation in the past three years, the firm is also likely to have reported other types of innovation, a finding supported by Clausen and Madsen (Chapter 5). Hence, Rønningen and Lien suggest that when measuring innovation in the tourism industry, it is better to use an overarching innovation orientation index rather than to differentiate between the different types of innovation.

Rønningen and Lien found in their survey that the majority of tourism firms are innovative to some extent. This finding is also supported by Clausen and Madsen (Chapter 5), who specifically analyzed innova- 
tions among experience-based tourism firms. However, these innovations differ not only in type but also in the extent to which they represent radical changes as perceived by the customer. The existing innovation literature classifies innovations according to how radical the innovations are. Continuous improvements are often characterized as incremental innovations whereas radical innovations represent more dramatic shifts in products, processes, and/or organizational forms (Fagerberg, 2005). A different conceptualization of the incremental-radical distinction was suggested by Christensen (1997), also emphasizing the 'creative destruction' element of innovation as introduced by Schumpeter (1934). When one market player introduces a disruptive innovation, other less innovative firms are likely to incur problems as customers move towards the new product that offers additional value to the consumer. Sustaining innovations, on the other hand, represent the improved performance of existing products and are likely to ensure the continuation of existing suppliers (Christensen, 1997). Hjalager (Chapter 3) uses Christensen's framework to examine innovation projects within the tourism industry in rural Denmark, analyzing whether this framework also can be used in this context. The researcher suggests that the extent of disruptiveness can be found in four sub-dimensions: the resource profile related to the value for customers, the production and provision of tourism products and, the way collaboration within and across sectors is utilized. Like Rønningen and Lien, Hjalager acknowledges that these dimensions of innovation may occur simultaneously. She develops an index of disruptive and sustaining innovation including these four sub-dimensions and uses this framework to categorize tourism innovation projects.

Eide and Ljunggren (Chapter 4) adopt a different approach by developing a framework for studying innovations as gendered. Innovation has generally been perceived as gender neutral and there is so far limited research on its gendered aspects. The tourism industry can be particularly interesting for a study of gendered innovation processes because the industry has a more balanced composition of women and men among employees, managers and owners compared to the manufacturing industries usually involved in innovation studies. Using examples from tourism firms, Eide and Ljunggren suggest that innovation processes involve interactions between actors, across organizations, and between organizations and their customers. Because these actors are women and men, gender becomes visible in these processes and influences their results. Hence, innovation processes can be studied as gendered systems of innovation. Eide and Ljunggren present a framework for analyzing how the gendering of innovation takes place within experience-based tourism. 


\section{SOURCES OF INNOVATION IN TOURISM INDUSTRIES}

The systemic nature of innovation has received extensive attention (Edquist, 2005) focusing on how firms innovate in collaboration and in interdependent relationships with other organizations. In their chapter, Rønningen and Lien (Chapter 2) find that systemic factors influence innovation in tourism firms. Appropriate relationships with external actors appear to be associated with higher innovation orientation within firms. In particular, cooperation with other firms and relationships with public support systems were associated with innovation, whereas few tourism firms had active relations with R\&D institutions. These researchers conclude that the tourism industry does not fit the criteria for an innovation system but instead fits the description of a loosely coupled system that promotes innovation (Sundbo \& Gallouj, 2000). The systemic approach to innovation appears to be particularly relevant in tourism because tourism firms are dependent upon each other to provide a product package interesting enough for tourists to choose to travel to particular destinations. Hence, innovations within this sector may not only be single new products or services provided by single firms but may also be new combinations of products and services from several firms put together in a package. Thus, innovations occur not only at the firm level but also at the destination level. The way in which innovation occurs at these two levels will be discussed in the next two sections.

The most important feature of innovation systems is the knowledge exchange that occurs in the system, whether it is an innovation system or a more loosely coupled system. As an element of a system, firms can obtain access to the information necessary to create and implement innovations. Clausen and Madsen (Chapter 5) examine the sources of knowledge that experience-based tourism firms use in their product innovation processes. Similar to Rønningen and Lien, Clausen and Madsen also found customers to be a highly important source of knowledge for innovation. In fact, nearly all firms used customers as a source of knowledge and the majority of firms considered this knowledge to be very important for innovation activities. This finding confirms the notable connection between customer interaction and innovation within experience-based tourism as explained above and elaborated on in several chapters of this book (e.g., Eide \& Ljunggren, Chapter 4, and Prebensen, Chapter 7). However, Clausen and Madsen also found suppliers, competitors and other tourism firms to be important sources of knowledge for innovation, which provides arguments regarding the systemic view of innovation in tourism industries.

$\mathrm{R} \& \mathrm{D}$ is generally not considered as an important source of innovation 
in the tourism sector, neither by scholars nor by the industry itself, as documented by Clausen and Madsen and supported by Rønningen and Lien's findings in Chapter 2. Traditionally, tourism industries have not been strongly connected to R\&D. However, the industry is increasingly beginning to demand R\&D-based knowledge to develop products related to cultural heritage or natural phenomena, for example. In Chapter 6, Sørensen and Sundbo demonstrate how research generated data concerning users can be used for innovation in tourism firms. Based on a userdriven innovation framework, these authors analyzed how GPS data on tourism mobility in a safari park provided important input into the innovation processes. Sørensen and Sundbo suggest that there are possibilities for extending user-based innovation in tourism based on research generated knowledge. Further, the authors indicate that user-based innovation processes in tourism will benefit from being organized as open innovation processes in which knowledge and inspiration for innovation can come from numerous sources.

Prebensen (Chapter 7) delves deeper into the role of customers as knowledge sources for innovation. Her study examines how generating knowledge about what tourists value in the process of booking, experiencing and remembering a tourist experience can contribute to the further development of experience products. Because the value created from tourism experiences is heavily dependent on the customer's involvement as a co-creator, tourism firms must facilitate customer participation in a way that contributes to value creation. This consideration requires firms to develop innovative solutions to motivate participation and to facilitate positive experiences, which is particularly challenging because different customers value the same experience in different ways. Hence, learning from customer experiences may prove extremely valuable in increasing innovation abilities among tourism firms. Prebensen presents examples of the ways in which firms can use customer information to provide enhanced value for tourists in the experience process.

To use knowledge from various sources for innovation, firms must acquire and adopt various types of knowledge, integrate the new types with existing knowledge and utilize this knowledge for innovation. These challenging tasks are discussed in the next section, which focuses on tourism firms as actors in innovation processes.

\section{TOURISM FIRM INNOVATION}

Innovations occur both through new business start-ups and within established firms. Two of the four chapters in the third section of the book 
examine new businesses or new business models. Alsos and Clausen (Chapter 8) explore the start-up processes of entrepreneurs within the tourism industry, whereas Furseth and Cuthbertson (Chapter 9) present a new framework that may represent one approach to business model innovation, the service innovation triangle. The two remaining chapters examine innovation in established firms. Brannon and Wiklund (Chapter 10) identify common business models used in the US wine industry, whereas Hall and Baird (Chapter 11) examine the levels of innovation in New Zealand wineries engaged in wine tourism and draw comparisons between the national and sector levels of innovation.

One important point of departure for these studies is that the tourism industry is undergoing transformation and that changing markets are associated with high uncertainty. In this situation, there are requests for new business models that can be used by new firms or by business model innovations in established firms. However, suggesting or adopting radical business model innovations is accompanied by high uncertainty. Further, competitive pressure, a lack of similar firms or models from which to learn, and a lack of information related to market size and customer demands make it difficult to analyze and predict whether new offerings or a changed business model are likely to be profitable. The contributions of Chapter 8 (Alsos \& Clausen) and Chapter 9 (Furseth \& Cuthbertson) include the development of knowledge to understand and overcome problems faced when starting up a new business or developing a new business model.

For example, Alsos and Clausen explore the extent to which tourism entrepreneurs follow causation (a planning-focused, goal-directed approach) and/or effectuation logic (an evolutionary approach associated with the adjustment of goals and strategies as the situation develops). These authors suggest that tourism entrepreneurs can be divided into the following four types: pure effectuationists, pure causationists, passive founders and ambidextrous entrepreneurs. Alsos and Clausen argue that because choices made at the start-up of new ventures may have persistent long-term imprinting effects on firm evolution, these choices may strongly influence the firm's later development (Stinchcombe, 1965; Hannan \& Freeman, 1989; Aldrich \& Martinez, 2001). Thus, knowledge regarding how the firm came to realization can signal prospective innovation and growth opportunities. Several similar contributions are provided by Furseth and Cuthbertson related to business model innovation, i.e., change in the business model of an organization. Based on their previously developed framework of the service innovation triangle (Furseth \& Cuthbertson, 2013), these authors describe nine integrated elements in the following three layers: innovation capacity, innovation ability, and innovation outcome. Through this model the authors seek to explain how 
business model innovation can be conducted in practice to create value for customers and hence for the firm.

Brannon and Wiklund (Chapter 10) and Hall and Baird (Chapter 11) focus on the ability of established firms with long traditions to innovate. Empirically, these authors study the emergence of wine tourism based on the traditional wine industry. Although wine tourism represents a growing branch within tourism, the industry has so far received limited attention and systematic research related to innovation. Whereas Hall and Baird provide an interesting overview of the levels of innovation in New Zealand wineries engaged in wine tourism and draw comparisons between the national and sectoral levels of innovation, Brannon and Wiklund complement these findings by providing new insights on how wine tourism firms use three different business models including agritourism, petite wineries and chateaus. Brannon and Wiklund show that innovation has helped these firms to succeed in a rural setting by developing interesting tourismrelated business activities.

\section{TOURISM DESTINATION INNOVATION}

The buzz words 'cooperate to compete' symbolize a paradigm shift from transactions to relationships in business-to-consumer (BTC) and businessto-business (BTB) markets (Sheth \& Parvatiyar, 1995). Similar relational shifts can be found in the theory and practice of management, production, learning and innovation. This turn represents a generic shift that is also observed within tourism. Enterprises working within the service economy or the experience economy benefit from, and perhaps depend on, cooperation with others in marketing, sales, production, packaging, learning and innovation. Similarly, numerous smaller and larger destinations and regions have discovered the benefit of cooperating rather than competing with their 'neighbors'. Because tourism operates in strongly competitive global markets, firms often must cooperate to position themselves, to develop a brand and to become attractive through interesting total products, extraordinary experience products and a functioning infrastructure. This relational (interactive) shift is also crucial to innovation (Sundbo, 2008). Fuglsang (2008) describes a move from one to three main paradigms: 'Schumpeter I', which focuses on the entrepreneur starting up and innovating the firm; 'Schumpeter II', which focuses on innovation through an R\&D staff, R\&D budget and patents; and the more recent 'Schumpeter III', which focuses on innovation as potentially involving ideas, resources, stakeholders and interactions situated within and across organizations, networks, destinations, etc. 
Abelsen, Eide, Kvidal and Leenheer (Chapter 12) address the role of cooperation in tourism for innovation by studying two cases in which three destination marketing organizations (DMOs) integrate into one larger organization. In one case, the merger began as cooperation and joint innovation at an informal level by learning how to cooperate and seeing a positive result, while the other case represents a top-down process to facilitate formal cooperation and merger. Building upon a framework of organizational innovation suggested by Lam (2005), the chapter demonstrates that organizational innovation as represented by restructuring provides no quick fix. Rather, these processes are complex and evolve over an extended time span. Learning throughout the process is crucial to making the new structures work. Abelsen et al. also discuss how the reorganization processes relate to other types of innovations, particularly marketing innovations, as marketing is the core activity of DMOs (Crouch \& Ritchie, 1999; Morgan et al., 2012).

Cooperation and innovation regarding destinations occur at several levels and do not only, or even mainly, involve DMOs. Another relational side of innovations is addressed by scholars studying networks, clusters, alliances, regional developments, and innovation systems as a way to facilitate learning and innovation. Tourism enterprises and other stakeholders can begin to interact informally or formally to learn, innovate, produce, or sell. Few network studies have been conducted within experience industries, and independent of industry, there is a significant knowledge gap regarding how and why networks emerge and develop (Ahuja et al. 2012; Clegg et al., 2012).

According to Newell et al. (2009), the studies of knowledge, learning and innovation through networks have adopted two main approaches: social network analysis (SNA) or network communities. The SNA approach focuses on networks as channels of knowledge flows. The network structure is mapped through the location of actors, nodes, relations, bottlenecks and sub-networks in informal or formal networks. Both qualitative and quantitative measures can be involved, such as how often actors interact or more qualitative characteristics such as connectivity, weak or strong ties and trust (Cross \& Parker, 2004; Cross \& Thomas, 2009). The network community approach tends to begin from knowledge as process and socially constructed, in which learning and innovation are situated and largely practice-based. Newell et al. (2009) identify at least three subtypes of networks:

(1) emerging, organic, informal and unmanaged networks, which can operate within or across organizations. This type of network has been described through concepts such as 'communities of practices' (CoPs) 
(Brown \& Duguid, 1991; Wenger, 2003) and 'innovative regional milieus' (Camagni, 1991; Maillat, 1998). Both concepts have been criticized for focusing too heavily on geographical proximity with regard to networks. For example, some tourism firms adopt a global approach and choose to become closely involved with organizations in other regions rather than becoming involved locally.

(2) Managed (network) communities represent networks in which actors seek to design or nurture the positive performance aspects of the first subtype through top-down creation and management. Online communities, for instance, Facebook groups.

Debates continue regarding whether networks can or should be designed and managed or whether networks must emerge and be 'left alone'. According to Eide and Fuglsang (2013) successful networking and interaction across enterprises in tourism depend upon 'scaffolding structures' that help actors to focus attention, mobilize, and create activities and infrastructure, which partially can be designed and partially can emerge. The vision of creating extraordinary experiences appears to be a powerful strategy. The experience economy mobilizes diverse and lifestyle-inspired subsectors into cooperation and innovation, creating what can be described as a bandwagon effect toward living out and developing tourism within the experience logic (Fuglsang \& Eide, 2013). Sørensen (2007) suggests that local and regional networks can be complementary; however, local networks appear insufficient because these networks can hamper the recognition of new knowledge that is often necessary for innovations (see also Bærenholdt et al., 2004). Hoarau, Wigger and Bystrowska (Chapter 13) study innovation as a response to climate change in an informal network of tourism stakeholders in Svalbard. These authors use the SNA approach in phase one of their data gathering and analysis to localize relations and sub-networks between actors, whereas in phase two they conduct interviews with some of the actors to obtain a more in-depth understanding (i.e., similar to the network community approach). The study shows that cooperation and informal networks at a local level are not enough because new and external knowledge are not absorbed and assimilated. The industry appears to retain previous perceptions, attitudes and practices rather than to proactively respond to the change in conditions through innovations. Therefore, the authors suggest organizing more formal and designed networks to facilitate external knowledge transfer and increased local learning and innovation. Such organization might depend upon the facilitation of organizations and structures and the involvement of other types of stakeholders, i.e., not only tourism enterprises.

When adopting a relational approach to innovation, stakeholders can 
be of different types such as DMOs and tourism firms. Other stakeholders include customers, facilitating organizations, consultants, research and educational institutes, and other industries. The last chapter in this book by Ren et al. (Chapter 14) examines knowledge flow, the negotiation of practices and innovation through interactions between the various types of stakeholders. This study uses a practice-based approach to learning and innovation (Gherardi, 2006), an approach similar to network communities as described by Newell et al. (2009). Ren et al. show how different communities operate within different practices and rationales that both influence and are influenced by new interactions such as those between students and tourism actors (enterprises and DMOs) at destination levels. For example, stakeholders operate with different understandings of innovations and different understandings of the characteristics of successful innovations. Students trained in innovation theory and given the task of analyzing and suggesting innovation for selected tourism destinations in Slovene are involved in designed arenas in which more theoretical knowledge meets practice-based knowledge and in which newcomers meet 'old timers' in the tourism sector and destinations. Ren et al. use the concept of 'proximity', understood in relation to recent knowledge not only as a matter of geography but also as a matter of closeness and distance as relational and practice-based. This approach means that one meeting is far from enough when facilitating knowledge transfer, absorption and innovation between tourism enterprises and university stakeholders.

\section{THE EXPERIENCE TURN IN TOURISM: CONSEQUENCES FOR INNOVATION RESEARCH}

Holbrook and Hirschman (1982) were among the first scholars to elaborate on the difference between hedonism and utilization when consuming products. Later Pine and Gilmore (1999) suggested that enterprises can add value by including experiences in production, for example, through entertainment. Humans have always enjoyed life through stories, play, entertainment, etc. What is new is the significant increase in the demand for and consumption of experience products and the increase of organizations (private, public, or voluntary) innovating, producing, and selling experiences as the main products. This trend, described as the experience economy, has received increasing attention by practitioners and scholars (Bærenholdt \& Sundbo, 2007; Sundbo \& Sørensen, 2013). At the macro level (society and sectors), value creation has moved from a primary focus on the production and sale of physical product values to service value, via 
solution value, and experience value (Gustafsson \& Johnson, 2003, p. 9). Pine and Gilmore (2011, p. 245) describe the same trend using the following phases: commodities, goods, services, experiences, and transformations. Others have described the new trend as 'the dream society' (Jensen, 1999).

Experience economy research is still in an early phase; however, this type of economy appears to function within a unique logic and with specific core characteristics that are partially different yet partially similar to the service economy, for example. Enterprises working with coffee, for example, can be involved in the following: making or transporting coffee beans, mass producing coffee for distribution, having waiters serve the coffee in a friendly manner at the proper time in the cafeteria, or running a coffee house involving the senses (e.g., smell, taste, touch, sight), including interactions, stories and pleasure. The latter scenarios use experience logic, whereas the earlier scenarios use service logic. One Norwegian example from tourism is the business model innovation adopted by the coastal steamer (Hurtigruten), a shipping line which for more than a hundred years has transported people and goods along the Norwegian coastline. The firm has moved from a service-logic business model and philosophy regarding the transportation of people and objects to an experience-based economy. The company has not only changed the ships and the reasons for using them but also has largely changed the interactions of customers with the enterprise. The business now cooperates with a large number of experience-based firms (e.g., nature-, culture- and foodbased experiences) when traveling up and down the coastline because customers book experience packages that occur outside the vessel. In addition, the enterprise has changed the interactions and involvement between the customers and the staff on the vessel; for example, chefs may be visible on the deck preparing freshly caught fish while customers enjoy watching, tasting and perhaps learning how to cook. The number of customers choosing the coastal steamer for transportation purposes only (pure transportation logic) has decreased, as has the number of customers attracted purely by the promise of a nice cabin or professional service by the staff or restaurant waiters. Instead, the majority of national and international customers are attracted by the potential for extraordinary nature-based experiences as the main product, good food and cultural experiences as the secondary product, and the total services as the tertiary product.

Tourism enterprises and destinations can work within different logics and not all have moved into the experience economy by creating experiences as their main products and the main reasons for customers to go. Some enterprises may work primarily within the service logic, 
focusing on services production (clean rooms, helpful receptions), service marketing and management (Grönroos, 1990; Gummesson, 1993; Ritzer, 1998; Ritzer \& Stillman, 2001). Some enterprises and destinations can be involved in a mix of approaches. However, when studying innovations in experience sectors, it is important to be aware of the fact that there are different logics and economies in which the tourism industry participates. One cannot take for granted that tourism firms are working within the logic of the experience economy; rather, this factor should be studied. For example, Clausen and Madsen (Chapter 5) and Alsos and Clausen (Chapter 8) study innovation in experience-based tourism by including questions that localized what type of products the enterprises were involved in and by excluding some of the respondents from the material. Conversely, Furseth and Cuthbertson (Chapter 9) elaborate specifically on service logic without any direct relation to experience logic.

Experience-based sectors are examined from different and partially overlapping theoretical perspectives such as experience economy, experience design (Jantzen et al., 2011), experience marketing (Mossberg, 2007) and consumer research (Arnould \& Price, 1993) in addition to more traditional perspectives such as psychology, sociology, anthropology, philosophy, economics, innovation, etc. Below we briefly present several chosen core characteristics of the experience economy (logic) based on a small sample of relevant literature concerning experience-based tourism (Pine \& Gilmore, 1999; Csikszentmihalyi, 2002; Mossberg, 2008; Carù and Cova, 2007; O’Dell \& Billing, 2005; Jantzen et al. 2011; Pedersen, 2012; Boswikj et al., 2012; Hansen \& Mossberg, 2013a; Eide \& Mossberg, 2013). These characteristics add complexity to innovation processes within experiencebased industries and are important for our understanding of how innovations best can be developed.

\section{The products}

We define experience products as mentally and/or bodily memorable experiences. Often the products are rather emotional. Experience products are similar to traditional products in that they can be partially physical objects. Additionally, these products are also similar to service products because they are partially intangible or intangible; therefore, the products cannot be fully produced and stored before the customer arrives because the customer participates in both the production and the consumption. One implication concerning the experience economy is that any studies of innovation types should expand the term 'product innovation' into three alternatives, i.e., physical, service and experience products. 


\section{Co-creation}

The consumption and use of services and goods also can be experiential (Sundbo \& Sørensen, 2013). Human beings experience, perceive and engage in making meaning and hence participate in the value creation of products and other interactions. These basic human characteristics are the focus of numerous humanistic and social disciplines that function within the interpretive scientific paradigm (see, e.g., Polkinghorne, 1988; Taylor, 1985; Bruner, 1990; Weick, 1995). As such, the consumption of products involves and depends on some degree of customer co-creation at the mental inner level. However, experience economy takes this concept further because customers more frequently expect to be involved in holistic, multi-dimensional and multi-leveled ways.

\section{Needs and motives}

Reasons to participate in tourism can be based on needs such as social belonging, meaning, self-realization and status. Customers seek newness, learning, belonging, hedonism, transformation, personal branding and identity. This demand requires creative, safe and smart ways to involve customers during experiences, in addition to professional experience design and innovation.

\section{Experience scapes}

The physical, social and symbolic environments in which experiences occur have been described as 'experience scapes' (Prahalad \& Ramaswamy, 2004), i.e., the space in which customer interactions and enjoyment take place (O'Dell, 2005). Whereas service scapes also occur amid interactions during service production (Bitner, 1992), experience scapes have been described as nested products created by actors' inputs through customer interactions (Mossberg, 2007).

\section{Customer interactions}

Whereas previous studies on service-based tourism have addressed the importance of personnel and other customers, recent studies on experiencebased tourism indicate that customer interactions are vital parts of experience products and the production process. Customer interaction types in tourism include interactions with personnel, other customers, other humans, animals, objects, and self. The degree and type of customer interactions can vary for different products and market segments, which increases the level of complexity, the need for improvising during production and the careful elaboration of customer interactions in experience design and innovation (Eide \& Mossberg, 2013; Eide and Ljunggren (Chapter 4), and Prebensen (Chapter 7)). Determining what types of 
customer interactions are the main value drivers or value drainers for customers can be important knowledge when working with innovations and developments. For example, Sørensen and Sundbo (Chapter 6) found that the opportunity to interact with animals is important when attracting customers to a safari park. However, interactions between customers in a group contribute the most to customer value. Further, one can argue that when products are produced and consumed with customers as active participants, the product and the production process becomes intertwined, which can make it difficult to separate product innovation from process innovation (see also Rønningen \& Lien, Chapter 2).

\section{Time dimension}

Experience businesses can focus on the following three main time phases in which customers are involved: before, during and after experiences (Carù \& Cuva, 2007). Eide and Mossberg (2013) indicate strong potential for innovation not only related to production and consumption but also to the phases before and after, which require different types of innovations.

\section{Experience design and innovation}

Experience production and consumption involve different senses and elements and extraordinary experiences involve peaks, flow, immersion, transformation, storytelling, and drama, for example, safe, enclaved and themed experiences, etc. (Hansen \& Mossberg, 2013b). The combinations of such dimensions are central when working with experience design and innovation. For example, Tarssanen and Kylänen (2006) suggest that the following six main dimensions should be addressed when creating meaningful and attractive experience designs and products: authenticity, individuality, history, contrast, sense, and interactions. In addition, one should relate the six dimensions to different levels in the customers' development, starting with motivation and ending with transformation. Others suggest that in contrast to goods and services, experience products are not a matter of functional value; instead, it is other values that customers seek (see, for example, Chapter 7 by Prebensen or Chapter 6 by Sørensen $\&$ Sundbo. Both address the importance of understanding customers' value creation). Therefore, one further implication for innovation is that understanding the different values and value creations of customers is vital knowledge when working with market-oriented experience design and innovations.

In sum, experience products can be dynamic, complex, multi-leveled, and multi-dimensional. These examples of the core characteristics of the experience economy can and should be addressed in innovation and 
development within experience-based tourism. Knowledge concerning the nature and role of experiences is vital when working with innovations and development in regard to products, processes, marketing, organization and other innovations that may be involved.

\section{CONCLUSIONS}

As presented in this chapter, this volume makes a broad take on innovation in tourism industries, bringing in a variety of perspectives and issues. Hence, evaluating the lessons derived from the 13 separate contributions in this volume is not an easy task. However, several clear themes emerge throughout the various chapters. First, the definition and measurement of innovation in tourism is not straightforward. There remains a need for improved measures on innovation in the tourism industry to enhance the understanding of how this sector's potential can be further developed and exploited. However, the tourism industry is not one homogenous industry but rather a heterogenic collection of different industries and industry branches, from transport and hotels to experience-based services and cultural offerings in which the package of services and products consists of contributions from numerous actors. This scenario creates a complex context for innovation that involves a variety of interacting actors and knowledge sources of which we have yet very limited understanding. Additional studies, both empirical and conceptual, are needed to obtain extended knowledge in this area.

Second, this book has presented chapters on firm-level innovation and destination-level innovation. It has also been noted that cooperation between firms facilitates the innovation ability of individual firms. Whereas firm-level innovation can be encouraged and supported by activities at the destination level, destinations cannot succeed without successful firms; hence, development at the firm level and at the destination level is highly interdependent. Further research is needed on the relationship between these two levels, including studies on how destinations and networks influence innovation at the firm level and vice versa. Presently there is a lack of empirical studies demonstrating the effect of cooperation on innovation capacity in tourism firms.

Third, the shift toward experience-based tourism raises some key challenges for innovation and innovation studies. Although the demand for and consumption of experienced-based services is significantly increasing, research on experience economy is still in an early phase. This area not only involves a range of different sectors but also presents challenges regarding experience-based products. Many of the products will 
be experienced or co-created because the customer participates both in production and consumption, as documented in the list of characteristics of experience-based tourism as presented in the previous section. The involved parties must essentially attempt to understand which types of customer interactions can be categorized as innovation and must determine the characteristics that are important for innovation and value creation. These production processes or co-creations are complex, dynamic and multi-leveled and therefore scarcely understood.

Fourth, taking into account the complexity and the multi-level nature of innovation in tourism industries, there is a need for multiple perspectives, theories and methods to examine and seek to understand these processes. The chapters in this volume take different perspectives and focus on the different aspects of innovation in tourism. They are based on data sources and data types from various contexts, and thus, represent the variety needed to be able to grasp the multiple facets of innovation in this sector. Although these studies provide important insights into the understanding of innovation within tourism industries, further research remains to be pursued in this area. We hope that this book can serve as a starting point for increased research related to innovation in tourism industries.

\section{REFERENCES}

Ahuja, G., G. Soda and A. Zaheer (2012). 'Introduction to the special issue: the genesis and dynamics of organizational networks', Organization Science, 23(2), 434-448.

Aldrich, H. E. and M. A. Martinez (2001). 'Many are called, but few are chosen: an evolutionary perspective for the study of entrepreneurship', Entrepreneurship Theory and Practice, 25(4).

Arnould, E. and L. Price (1993). 'River magic: extraordinary experience and the extended service encounter', Journal of Consumer Research, 20 (June), $24-45$.

Bærenholdt, J. O. and J. Sundbo (eds) (2007). Oplevelsesøkonomi. Produktion, forbrug og kultur (Experience Economy. Production, Consumption, Culture), Copenhagen, Denmark: Samfundslitteratur.

Bærenholdt, J. O., M. Haldrup, J. Larsen and J. Urry (2004). Performing Tourist Places, Aldershot, UK: Ashgate.

Bitner, M. J. (1992). 'Servicescapes: the impact of physical surroundings on customers and employees', Journal of Marketing, 56, 57-71.

Boswijk, A., E. Peelen and S. Olthof (2012). The Economy of Experiences, Amsterdam, Netherlands: Peason Education Benelux.

Brown, J. S. and P. Duguid (1991). 'Organizational learning and communities-of-practice: toward a unified view of working, learning, and innovation', Organization Science, 2(1), $40-57$.

Bruner, J. (1990). Acts of meaning, Cambridge, MA, USA: Harvard University Press.

Camagni, R. (1991), 'Introduction: from the local "milieu" to innovation through cooperation networks', in R. Camagni (ed.), Innovation Networks: Spatial Perspectives, London, UK: Belhaven Press, pp. 1-9.

Camisón, C. (2000). 'Strategic attitudes and information technologies in the hospitality 
business: an empirical analysis', International Journal of Hospitality Management, 19, $125-143$.

Camisón, C. and V. M. Monfort-Mir. (2012). 'Measuring innovation in tourism from the Schumpeterian and the dynamic-capabilities perspectives', Tourism management, 33(4), 776-789.

Carù, Antonella and Bernard Cova (2007). 'Consumer immersion in an experiential context', in Antonella Carù and Bernard Cova (eds), Consuming Experience, London, UK: Routledge, pp. $34-47$.

Christensen, C. M. (1997). The Innovator's Dilemma, Cambridge, MA, USA: Harvard Business School Press.

Clegg, S., E. Josserand, A. Mehra and T. Pitsis (2012). Call for papers: Special Issue on 'The transformative and innovative power of network dynamics', Organizational Studies, available at http://www.egosnet.org/organization_studies/special_issues_cfps_guidelines_for_ proposal submissions/call_for_papers (last accessed 9 May 2012).

Cross, R. L. and A. Parker (2004). The Hidden Power of Social Networks: Understanding How Work Really Gets Done in Organizations, Boston, MA, USA: Harvard Business School Press.

Cross, R. and R. J. Thomas (2009). Driving Results through Social Networks: How Top Organizations Leverage Networks for Performance and Growth, San Francisco, CA, USA: John Wiley \& Sons.

Crouch, G. and R. Ritchie (1999). 'Tourism, competitiveness, and societal prosperity', Journal of Business Research, 44, 137-152.

Csikszentmihalyi, M. (2002). Flow, London, UK: Rider.

Drejer, I. (2004). 'Identifying innovation in surveys of services: a Schumpeterian perspective', Research Policy, 33(3), 551-562.

Edquist, C. (2005). 'Systems of innovation: perspectives and challenges', in J. Fagerberg, D. C. Mowery and R. R. Nelson (eds), The Oxford Handbook of Innovation, Oxford, UK: Oxford University Press, pp. 181-208.

Eide, D. and Fuglsang, L. (2013). 'Networking in the experience economy: Scaffolded networks between designed and emerging regional development', in J. Sundbo and F. Sørensen (eds), Handbook on the Experience Economy. Cheltenham, UK and Northampton, MA, USA: Edward Elgar Publishing, pp. 287-309.

Eide, D. and L. Mossberg (2013). 'Towards a conceptual framework of innovation types in experience economy: innovation through experience design with focus on customer interactions', in J. Sunbo and F. Sørensen (eds.). Handbook on the Experience Economy, Cheltenham, UK and Northampton, MA, USA: Edward Elgar, pp. $248-268$.

Fagerberg, J. (2005). 'Innovation. A guide to the literature.', in J. Fagerberg, D. C. Mowery and R. R. Nelson (eds), The Oxford Handbook of Innovation, Oxford, UK: Oxford University Press, pp. 1-26.

Fuglsang, L. (2008). 'Innovation with care: what it means', in L. Fuglsang (ed.), Innovation and the Creative Process: Towards Innovation With Care, Cheltenham, UK and Northampton, MA, USA: Edward Elgar, pp. 3-21.

Fuglsang, L. and D. Eide (2013). 'The experience turn as bandwagons: understanding network formation and innovation as practice', European Urban and Regional Studies, 20(4), 418-435.

Furseth, P. I. and R. W. Cuthbertson (2013). 'The Service Innovation Triangle: a tool for exploring value creation through service innovation', Journal of Technology Marketing, forthcoming.

Gallouj, F. and F. Djellal (2010). 'Introduction: filling the innovation gap in the service economy - a multidisciplinary perspective', in F. Gallouj and F. Djellal (eds), The Handbook of Innovation and Services: A Multi-Disciplinary Perspective, Cheltenham, UK and Northampton, MA, USA: Edward Elgar, pp. 1-23.

Gallouj, F. and J. Sundbo (1998). Innovation in Services in Seven European Countries, Roskilde, Denmark: Roskilde University. 
Gallouj, F. and M. Savona (2010).'Towards a theory of innovation in services: a state of the art', in F. Gallouj and F. Djellal (eds), The Handbook of Innovation and Services: A Multi-disciplinary Perspective, Cheltenham, UK and Northampton, MA, USA: Edward Elgar, pp. $27-48$.

Gherardi, S. (2006). Organizational Knowledge: The Texture of Workplace Learning, Oxford, UK: Blackwell.

Grönroos, C. (1990). Service Management and Marketing, Lexington, MA, USA: Lexington Books.

Gummesson, E. (1993). Quality Management in Service Organizations, New York, USA: St John's University and International Service Quality Association.

Gustafsson, Anders and Michael Johnson (2003). Competing in a service economy, San Francisco, CA, USA: Jossey-Bass.

Hall, C. M. (2009). 'Innovation and tourism policy in Australia and New Zealand: never the twain shall meet?', Journal of Policy Research in Tourism, Leisure and Events, 1(1), 2-18.

Hall, C. M. and A. M. Williams (2008). Tourism and innovation, London, UK: Routledge.

Hannan, M. T. and J. Freeman (1989). Organizational Ecology, Cambridge, MA, USA: Harvard University Press.

Hansen, A.-H. and L. Mossberg (2013a). 'Consumer immersion in a tourism experience context', in J. Sundbo and F.Sørensen (eds), Handbook on the Experience Economy, Cheltenham, UK and Northampton, MA, USA: Edward Elgar, pp.209-227.

Hansen, A.-H. and L. Mossberg (2013b). 'Tour guides and tourists' immersion', unpublished paper presented at MME-research seminar 28 May, Bodø Graduate School of Business, Bodø.

Hipp, C. and H. Grupp (2005). 'Innovation in the service sector: the demand for servicespecific innovation measurement concepts and typologies', Research Policy, 34(4), 517-535.

Hjalager, A.-M. (1997). 'Innovation patterns in sustainable tourism - an analytical typology', Tourism Management, 18(1), 35-41.

Hjalager, A.-M. (2002). 'Repairing innovation defectiveness in tourism', Tourism Management, 23, 465-474.

Hjalager, A.-M. (2010). 'A review of innovation research in tourism', Tourism management, 31(1), 1-12.

Hjalager, A.-M., E. Huijbens, P. Björk, S. Nordin, A. Flagestad and O. Knutsson (2008). Innovation systems in Nordic tourism. Oslo, Norway: NICe. Available at http://www.nor dicinnovation.net/prosjekt.cfm?Id1/41-4415-282 (last accessed 18 May 2013).

Holbrook, M. B. and E. C. Hirschman (1982). 'The experiential aspects of consumption: consumer fantasies, feelings, and fun', Journal of Consumer Research, 9(2), 132-40.

Jacob, M., J. Tintoré, E. Aguiló, A. Bravo and J. Mulet (2003). 'Innovation in the tourism sector: results from a pilot study in the Balearic Islands', Tourism Economics, 9(3), 279-295.

Jantzen, C., M. Vetner and J. Bouchet (2011). Oplevelsesdesign (Experience Design), Fredriksberg: Samfundslitteratur.

Jensen, R. (1999). The Dream Society: How the Coming Shift from Information to Imagination will Transform your Business, Copenhagen, Denmark: Jyllandspostens Forlag.

Johannessen, J. A., B. Olsen and G. T. Lumpkin (2001). 'Innovation as newness: what is new, how new, and new to whom?', European Journal of Innovation Management, 4(1), 20-31.

Jolly, D. and F. Dimanche (2009). 'Investing in technology for tourism activities: perspectives and challenges', Technovation, 29, 576-579.

Krizaj, D., A. Brodnik and B. Bukovec (2012). 'A tool for measurement of innovation newness and adoption in tourism firms', International Journal of Tourism Research, available at http://onlinelibrary.wiley.com/doi/10.1002/jtr.1905/full (last accessed 8 September 2013).

Lam, A. (2005). 'Organizational innovation', in J. Fagerberg, D. Mowery and R. Nelson (eds), The Oxford Handbook of Innovation, Oxford: Oxford University Press.

Law, R. and G. Jogaratnam (2005). 'A study of hotel information technology applications', International Journal of Contemporary Hospitality Management, 17(2), 170-180. 
Liburd, J. J. (2012). 'Tourism research 2.0', Annals of Tourism Research, 39(2), 883-907.

López-Fernández, M. C., A. M. Serrano-Bedia and R. Gómez-López (2009). 'La Decisión de Innovar de las Empresas Turísticas: Un Análisis Empírico de la Industria Hostelera', Investigaciones Europeas de Dirección y Economía de la Empresa, 15(3), 169-182.

Lordkipanidze, M., H. Brezet and M. Backman (2005). 'The entrepreneurship factor in sustainable tourism development', Journal of Cleaner Production, 13, 787-798.

Maillat, D. (1998), 'Innovative milieux and new generations of regional policies', Entrepreneurship and Regional Development, 10(1), 1-16.

Martínez-Ros, E. and F. Orfila-Sintes (2009). 'Innovation activity in the hotel industry', Technovation, 29(9), 632-641.

Miles, I. (2005).'Innovation in services', in J. Fagerberg, D. C. Mowery and R. R. Nelson (eds), The Oxford Handbook of Innovation, New York, USA: Oxford University Press, pp. $433-458$.

Morgan, N., E. Hastings and A. Pritchard (2012). 'Developing a new DMO marketing evaluation framework: the case of Visit Wales', Journal of Vacation Marketing, 18(1), 73-89.

Mossberg, L. (2007). 'A marketing approach to the tourist experience', Scandinavian Journal of Hospitality and Tourism, 7(1), 59-74.

Mossberg, L. (2008). 'Extraordinary experiences through storytelling', Scandinavian Journal of Hospitality and Tourism, 8(3), 195-210.

Newell, S., M. Robertson, H. Scarbrough and J. Swan (2009). Managing Knowledge Work and Innovation, Hampshire, UK: Palgrave Macmillan.

Novelli, M., Schmitz, B. and T. Spencer (2006). 'Networks, clusters and innovation in tourism: a UK Experience', Tourism Management, 27(6), 1141-1152.

O'Dell, T. (2005). 'Experiencescapes: blurring borders and testing connections', in T. O'Dell and P. Billing (eds), Experiencescapes - Tourism, Culture, and Economy, Copenhagen, Denmark: Copenhagen Business School Press, pp. 11-33.

O'Dell, T. and P. Billing (eds) (2005). Experiencescapes - Tourism, Culture, and Economy, Copenhagen, Denmark: Copenhagen Business School Press.

OECD and Statistical Office of European Communities (2005). Oslo Manual: Guidelines for collecting and interpreting innovation data (3rd ed.), Paris, France: OECD, Organisation for Economic Co-operation and Development.

OECD (2010). Tourism trends and policies 2010, Paris, France: OECD, Organisation for Economic Co-operation and Development.

Orfila-Sintes, F., R. Crespi-Cladera and E. Martínez-Ros (2005). 'Innovation activity in the hotel industry: evidence from Balearic hotels', Tourism Management, 26(6), 851-865.

Pedersen, A.-J. (2012). Opplevelsesøkonomi. Kunsten å designe opplevelser, Oslo, Norway: Cappelen Damm Akademisk.

Pine, B. J. and J. H. Gilmore (1999). The Experience Economy. Work is Theatre and Every Business a Stage, Boston, MA, USA: Harvard Business School Press.

Pine, B. J. and J. H. Gilmore (2011). The experience economy, Boston, MA, USA: Harvard Business School Press.

Polkinghorne, D. E. (1988). Narrative Knowing and the Human Sciences, Albany, NY, USA: State University of New York Press.

Prahalad, C. K. and V. Ramaswamy (2004). 'Co-creating unique value with customers', Strategy and Leadership, 32(3), 4-9.

Ritzer, G. (1998). The McDonaldization, London, UK: Sage.

Ritzer, G. (2008). The McDonaldization of Society, Thousand Oaks, CA, USA: Pine Forge Press.

Ritzer, G. and T. Stillman (2001). 'From person - to system-oriented service', in A. Sturdy, I. Grugulis and H. Willmott (eds), Customer Service, London, UK: Palgrave Macmillan, pp. 102-116.

Schumpeter, J. A. (1983[1934]). The Theory of Economic Development, New Brunswick, NJ, USA: Transaction Publishers.

Sheth, J. N. and A. Parvatyar (1995). 'The evolution of relationship marketing', International Business Review, 4(4), 397-415. 


\section{Handbook of research on innovation in tourism industries}

Sørensen, F. (2007). 'The geographies of social networks and innovation in tourism', Tourism Geographies, 9(1), 22-48.

Stinchcombe, A. L. (1965). 'Social structures and organizations', in J. G. March (ed.), Handbook of Organizations, Chicago, IL, USA: Rand McNally, pp. 142-193.

Sundbo, J. (2008). 'Innovation and involvement in services', in L. Fuglsang (ed.), Innovation and the Creative Process. Towards Innovation with Care, Cheltenham, UK and Northampton, MA, USA: Edward Elgar, pp. 87-111.

Sundbo, J. and F. Gallouj (2000). 'Innovation as a loosely coupled system in services', International Journal of Services Technology and Management, 1(1), 15-36.

Sundbo, J. and F. Sørensen, (2013). 'The experience economy and experience economy studies', in J. Sunbo and F. Sørensen (eds). Handbook on the Experience Economy, Cheltenham, UK and Northampton, MA, USA: Edward Elgar, pp. 1-17.

Sundbo, J., F. Orfila-Sintes and F. Sørensen (2007). 'The innovative behaviour of tourism firms - Comparative studies of Denmark and Spain', Research Policy, 36(1), 88-106.

Sundbo, J., F. Sørensen and L. Fuglsang (2010). 'Innovation in the Experience Sector', Research Report No. 10:7, Roskilde: Centre of Service Studies, Roskilde University.

Tarssanen, S. and M. Kylänen (2006). 'What is an experience?', in S. Tarssanen (ed.), Handbook for Experience Tourism Agents, Rovaniemi, Finland: University of Lapland Press, pp. 8-23.

Taylor, C. (1985). Human Agency and Language, Philosophical Papers, vol. 1, Cambridge, UK: Cambridge University Press.

Tribe, J. (1997). 'The indiscipline of tourism', Annals of Tourism Research, 24(3), 638-657.

Vence, X. and A. Trigo (2009). 'Diversity of innovation patterns in services', The Service Industries Journal, 29(12), 1635-1657.

Volo, S. (2004). 'Foundation for an innovation indicator for tourism', in P. Keller and T. Bieger (eds), The future of small and medium-sized enterprises in tourism, St. Gallen, Switzerland: AIEST, pp. 361-376

Walder, K., K. Bailey and A.S. Perez (2006). Innovation and Product Development in Tourism: Creating Sustainable Competitive Advantage. Berlin, Germany: Erich Schmidt Verlag.

Weick, K. E. (1995). Sensemaking in Organizations, Thousand Oaks, CA, USA: SAGE Publications.

Weiermair, K. (2006). 'Prospects for Innovation in Tourism', Journal of Quality Assurance in Hospitality \& Tourism, 6(3-4), 59-72.

Wenger, E. (2003). 'Communities of practice and social learning systems', in D. Nicolini, S. Gherardi and D. Yanow (eds), Knowing in Organizations: A Practice-based Approach, New York, USA: M. E. Sharpe, pp. 76-99.

Weth, A. (2007). Innovations and Creativity - How Disney Keeps Ideas Coming, München, Germany: GRIN verlag. 